Güdenoğlu, E. (2021). "Petrol Fiyatlarının İstihdam Üzerindeki Asimetrik Etkileri: Türkiye Örneğinde NARDL Yaklaşımı Bulguları”, Eskişehir Osmangazi Üniversitesi iỉß Dergisi, 16(2), 381 - 400.

Doi: 10.17153/oguiibf.885601

Başvuru: 23.2.2021 Kabul: 14.04.2021

Araştırma Makalesi/Research Article

\title{
Petrol Fiyatlarının İstihdam Üzerindeki Asimetrik Etkileri: Türkiye Örneğinde NARDL Yaklaşımı Bulguları
}

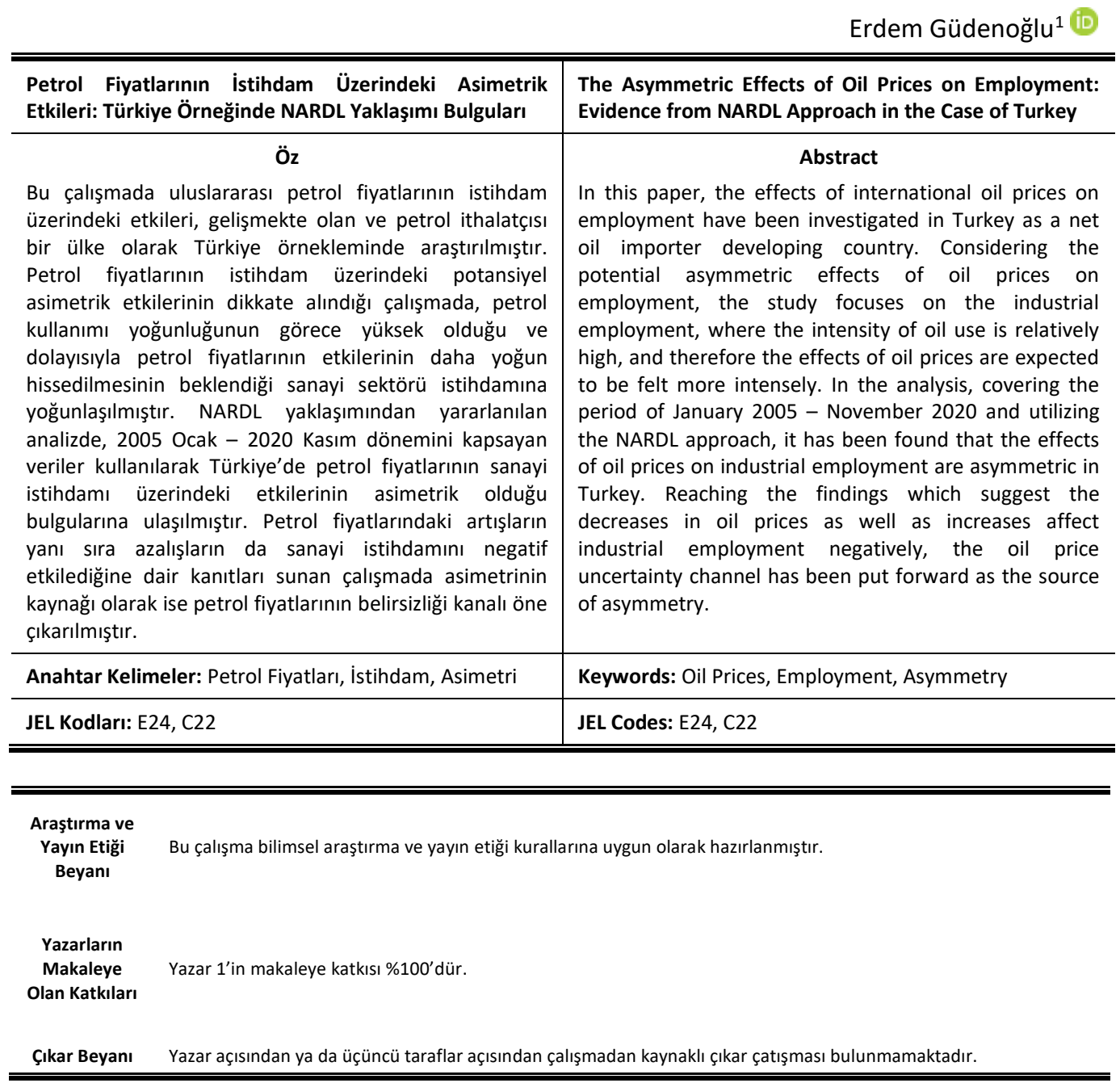

\footnotetext{
${ }^{1}$ Arş. Gör. Dr, Zonguldak Bülent Ecevit Üniversitesi, iiBF, i̇ktisat, erdem.gudenoglu@beun.edu.tr
} 


\section{Giriş}

Petrol fiyatları ve ekonomik aktivite arasındaki ilişki güncelliğini koruyan bir araştırma alanı olarak göze çarpmaktadır. Söz konusu ilişkinin iktisadi literatürde bu yoğunlukta tartışılmasının kökenlerine bakıldığında ise 1973 yılı son çeyreğinde petrol ihracatçısı Arap ülkelerinin ABD, Hollanda gibi ülkelere ambargo uygulamasıyla ortaya çıkan petrol krizinin öne çıktığı görülmektedir. Uluslararası piyasada petrol fiyatlarının önemli ölçüde artmasına yol açan bu gelişme ve devamında gözlemlenen makroekonomik gerçekleşmeler, araştırmacıların petrol fiyat şoklarının iktisadi faaliyet üzerindeki etkilerine yoğunlaşmasına yol açmıştır. Başlangıçta, başta ABD olmak üzere gelişmiş ülke örneklemlerinde, ağılıklı olarak petrol fiyat şoklarının üretim maliyetleri ve arz üzerindeki etkilerine dikkat çekilen çalışmalarda, petrol fiyatları ile ekonomik performans arasındaki potansiyel negatif ilişki sorgulanmıştır (Brown vd., 2003: 2).

Petrol fiyat artışlarının etkilerini sorguladığı öncü çalışmasında Hamilton (1983), II. Dünya Savaşı sonrası ABD'de ortaya çıkan durgunlukların petrol fiyatlarındaki dramatik artışları takip ettiği gözleminden hareketle, petrol şoklarının iktisadi faaliyetteki daralmayı anlamlı bir şekilde açıkladığına dair bulgular sunmuştur. Hamilton'un (1983) ses getiren çalışmasını takiben ortaya konulan çalışmalarda ise farklı gelişmiş ülke örneklemleri ve farklı yöntemlerle bulgular desteklenmiş (Burbidge ve Harrison, 1984; Gisser ve Goodwin, 1986), petrol fiyatlarının iktisadi faaliyet üzerindeki etkisine aracılık eden farklı kanallara dikkat çekilmiş (Loungani, 1986), ilişkinin zaman içerisindeki sürekliliği tartışılmış (Hooker, 1996), petrol fiyatlarının iktisadi faaliyet üzerindeki asimetrik etkileri sorgulanmıştır (Mork, 1989; Ferderer, 1996).

Literatür incelendiğinde, petrol fiyat şoklarının ekonomi üzerindeki etkilerinin ağırlıklı olarak petrol fiyatları - üretim düzeyi bağlamında ele alındığı ve ABD başta olmak üzere gelişmiş ülkelere yoğunlaşıldığı görülmektedir. Diğer taraftan petrol fiyatlarının emek piyasası üzerindeki etkilerinin sorgulandığı çalışmalarda ise bu etkilerin genellikle işsizlik oranları kullanılarak araştırıldığı göze çarpmaktadır. Gelişmekte olan bir ülke olarak Türkiye ise gelişmiş ülkelerden ve petrol üreticisi ülkelerden, petrol arzı ve talebi dolayısıyla petrol fiyatları üzerinde belirleyiciliği olmaması nedeniyle ayrışmaktadır. Diğer taraftan net petrol ithalatçısı bir ülke olarak Türkiye'nin ekonomik faaliyetini sürdürebilmesi için petrole olan bağımlılığı, petrol fiyatlarındaki değişimlerin ekonomik etkilerinin daha belirgin olmasına yol açmaktadır. (Alper ve Torul, 2010: 1).

Bu çalışmada petrol ithalatçısı gelişmekte olan bir ülke olan Türkiye örnekleminde petrol fiyatlarındaki değişimlerin istihdam üzerindeki asimetrik etkileri, petrol kullanımı yoğunluğunun görece yüksek olduğu ve dolayısıyla petrol fiyat değişimlerinin etkilerinin daha yoğun hissedilmesinin beklendiği sanayi sektörü özelinde incelenmiştir. Bu bağlamda çalışmada; Türkiye'de petrol fiyatları ve sanayi istihdamı arasında uzun dönemli bir ilişki olup olmadığı, varsa bu ilişkinin asimetrik olup olmadığı, asimetri geçerli ise petrol fiyatlarının asimetrik etkisinin ortaya çıkmasında hangi geçiş kanallarının etkili olduğu sorularına cevap aranmıştır. Petrol fiyatlarının ekonomik etkilerinin Türkiye örnekleminde araştırıldığı çalışmalarda genel olarak gelir düzeyi, sanayi üretimi, enflasyon oranları gibi makro sonuç büyüklükleri konu edinilmiş; emek piyasasındaki etkilerin analizinde ise ağırlıklı olarak işsizlik oranlarına odaklanılmıştır. Diğer taraftan literatürü oluşturan çalışmalarda petrol fiyatları ve ekonomik faaliyet arasındaki ilişki çoğunlukla doğrusal yöntemlerle sorgulamış sınırlı sayıda çalışmada ise doğrusallık, yapısal kırılmaların modellere dâhil edilmesiyle esnetilmiştir. Bu 
çerçevede asimetrik etkilerin araştıııldığı bu çalışma ile gerek petrol fiyatlarının istihdam üzerindeki etkilerinin ortaya çıkarılması gerekse potansiyel asimetrik etkilerin yönünün ve boyutunun belirlenmesi yönlerinden literatüre daha güncel veriler ve yöntemlerle katkı sunulması amaçlanmıştır.

Çalışmanın müteakip bölümü petrol fiyatlarındaki değişimlerin ekonomik etkilerinin ortaya çıkmasında aracılık eden kanallar bağlamında konunun teorik çerçevesinden oluşmaktadır. Üçüncü bölüm petrol fiyatlarının ekonomik etkilerinin araştırıldığı öne çıkan ampirik çalışmaların ve bulgularının ifade edildiği literatür özetidir. Dördüncü bölümde petrol fiyatları ve istihdam arasındaki asimetrik ilişki NARDL yaklaşımı kullanılarak ekonometrik olarak analiz edilmiştir. Son bölüm ise çalışmanın genel sonuçlarının değerlendirildiği ve politika önerilerinin sunulduğu sonuç bölümüdür.

\section{Teorik Çerçeve}

Petrol fiyatlarındaki değişimlerin ekonomi üzerindeki etkilerinin tartışıldığı çalışmalarda söz konusu etkilerin ortaya çıkmasına aracılık eden bir takım kanallar ön plana çıkarılmaktadır. Bunlardan ilki bir üretim girdisi ve hammadde olarak petrol fiyatlarındaki artışların firmaların üretim maliyetlerinin artışı olarak ele alındığı klasik arz şoku kanalıdır. Üretimin en temel girdisi olarak enerji maliyetlerindeki artışlara dikkat çekilen bu yaklaşıma göre petrol fiyatlarındaki artışlar üretimi ve istihdamı negatif etkileyecektir (Brown vd., 2003: 3).

Petrol fiyatlarındaki artışlar yerel düzeyde petrol tüketicilerinden üreticilerine doğru, uluslararası düzeyde ise petrol ithalatçısı ülkelerden ihracatçı ülkelere doğru bir gelir transferinin ortaya çıkmasına sebep olacaktır. Buradan hareketle ihracatçı ülkelerde satın alma gücünün artacağının, ithalatçı ülkelerde ise satın alma gücünün ve toplam talebin düşeceğinin öne çıkarıldı̆̆ı yaklaşım ise gelir transferi kanalı olarak tanımlanmaktadır (Lardic ve Mignon, 2008: 848).

Bir üretim girdisi olarak petrol fiyat artışları, firmaların fiyatları yükseltemedikleri koşullarda kârlılıklarının azalmasına yol açacaktır (Mussa, 2000: 13). Firmalar maliyet artışlarını telafi edebilmek için fiyatları yükselttiğinde ise ekonomide enflasyonist bir baskı ortaya çıkacaktır. Fiyatlardaki artışın reel balans etkisine dikkat çekilen reel balans kanalı yaklaşımına göre portföylerini likidite bakımından dengelemek isteyen ekonomik aktörlerin artan para talebine parasal otoritenin karşılık verememesi faiz oranlarının artmasına, ekonomik faaliyetin ise daralmasına yol açabilecektir (Mork, 1994: 21; Lardic ve Mignon, 2008: 848). Diğer taraftan petrol fiyat artışlarının fiyatlar genel seviyesini yükseltmesi, enflasyon hedeflemesi yapan parasal otoriteyi sıkı para politikası uygulamaya yönlendirebilecektir (Ferderer, 1996: 2; Bernanke vd., 1997: 136). Petrol fiyat şoklarının geçici olduğu beklentisinin hâkim olduğu koşullarda ise tüketiciler tüketimlerinin azalmaması için daha az tasarrufta bulunup daha fazla borçlanma talebi içerisine girebileceklerdir. Borçlanma talebinin artması faiz oranlarını artıracak, artan faiz oranları yatırımları ve dolayısıyla üretimi ve istihdamı azaltacaktır. Bu çerçevede petrol fiyat şoklarının parasal etkilerle ekonomide daralmaya yol açması, para politikası kanalı olarak tanımlanmaktadır (Brown vd., 2003: 4). Para politikası kanalı aracılığıyla ortaya çıkan etkiler, arz şoklarını takiben ve enflasyon karşıtı önlemlerin sonucu olarak ortaya çıkmaları nedeniyle ikinci raunt etkileri olarak da adlandırılmaktadır (Mussa, 2000: 35).

Petrol şoklarının ekonomiye etkisinin doğrudan emek piyasasının kompozisyonu üzerinden gerçekleşebileceğinin ifade edildiği emeğin yeniden dağılımı kanalına göre ise petrol fiyat 
şokları sonrası göreceli fiyatlar değişecektir. Bu değişim, başta emek ve sermaye olmak üzere, üretici güçlerin görece daha kârlı alanlarda istihdam olanağı aramalarına yol açacağından bir uyumlanma süresi ve maliyeti ortaya çıkarabilecektir (Ferderer, 1996: 3). Bu çerçevede petrol fiyatlarındaki artışların üretimde yapısal değişimlere yol açabileceğine dikkat çeken Lardic ve Mignon'a (2008) göre fiyat şokları uzun süreli olmaları halinde istihdamın kompozisyonu değiştirebilecektir. Özellikle üretimde petrolün yoğun olarak kullanıldığı sektörlerde fiyat artışlarının sürekliliği, üretim süreçlerinde yenilik ihtiyacı doğuracak, emeğin ve sermayenin yeniden dağılımı nedeniyle istihdamda önemli etkiler ortaya çıkabilecektir.

Petrol fiyat şoklarının ekonomiye geçişine aracılık eden belirsizlik kanalı yaklaşımı ise petrol fiyatlarında dalgalanmaların yoğun olduğu dönemlerde kendini hissettiren fiyat öngörülemezliğinin yatırım kararları üzerindeki negatif etkisine vurgu yapmaktadır. Bu yaklaşıma göre belirsizlik ortamı yatırımların ertelenmesine yol açacak ve dolayısıyla üretimi ve istihdamı azaltacaktır. Diğer taraftan petrol fiyatlarının belirsizliği, firmaları fiyatlandırma konusunda da bir belirsizliğe düşüreceğinden piyasayı yatırımcılar için daha az güvenilir hale getirerek faiz oranlarının artmasına yol açabilecektir. Bu çerçevede petrol fiyatlarındaki belirsizliğin ekonomik aktiviteyi zayıflatacağı beklenmektedir (Brown vd., 2003: 8). Belirsizlik kanalı özellikle petrol fiyat şoklarının iktisadi faaliyet üzerindeki asimetrik etkilerini açıklayabilmesi yönüyle öne çıkmaktadır. Bu yaklaşıma göre petrol fiyatlarındaki belirsizlik durumunda fiyat artışları gibi fiyat azalışlarının da ekonomi üzerinde negatif etkisi ortaya çıkabilecektir (Mork, 1994: 35).

Bu bilgiler çerçevesinde oluşturulan Tablo 1'de, pozitif petrol fiyat şokları baz alınarak bu şokların reel ekonomik faaliyete geçişinde aracılık eden kanallar, geçiş dinamikleri ve ekonomik faaliyet üzerindeki etkileri özetlenmiştir.

Tablo 1: Petrol Fiyat Şoklarının Geçiş Kanalları ve Dinamikleri

\begin{tabular}{lll}
\hline Geçiş Kanalı & Geçiş Dinamiği & Beklenen Etki \\
\hline Arz şoku kanalı & Üretim maliyetlerinde artış & Simetrik \\
\hline $\begin{array}{l}\text { Gelir transferi } \\
\text { kanalı }\end{array}$ & $\begin{array}{l}\text { Petrol tüketicilerinden üreticilere, } \\
\text { ithalatçı ülkelerden ihracatçı ülkelere } \\
\text { doğru gelir transferi }\end{array}$ & Simetrik \\
\hline $\begin{array}{l}\text { Reel balans } \\
\text { kanalı }\end{array}$ & $\begin{array}{l}\text { Reel balans talebinin ve faiz oranlarının } \\
\text { yükselmesi }\end{array}$ & Simetrik \\
\hline $\begin{array}{l}\text { Para politikası } \\
\text { kanalı }\end{array}$ & $\begin{array}{l}\text { Enflasyonist baskı sonucu parasal } \\
\text { otoritenin enflasyon karşıtı önlem alması }\end{array}$ & $\begin{array}{l}\text { Enflasyon hedefli MB: Simetrik } \\
\text { Enflasyon hedeflemeyen MB: }\end{array}$ \\
\hline $\begin{array}{l}\text { Emeğin yeniden } \\
\text { dağlımı kanalı }\end{array}$ & $\begin{array}{l}\text { İşgücünün daha kârlı sektörlere mobilize } \\
\text { olması }\end{array}$ & Simetrik ve asimetrik \\
\hline Belirsizlik kanalı & Maliyet ve fiyatlama öngörülemezliği & Asimetrik \\
& sonucu yatırımların azalması & \\
\hline
\end{tabular}

Kaynak: Yazar tarafından oluşturulmuştur.

Tablo 1'de özetlenen bilgilere göre arz şoku, gelir transferi ve reel balans kanalları; petrol fiyatlarının ekonomik faaliyet üzerindeki simetrik etkilerini açıklamada güçlü iken para politikası, emeğin yeniden dağılımı ve belirsizlik kanalları ise petrol fiyatlarının asimetrik etkilerine de teorik olarak bir takım açıklamalar getirebilmektedirler. 


\section{Literatür Özeti}

Petrol fiyatlarının iktisadi faaliyet üzerindeki etkilerinin konu edildiği çok sayıda ampirik çalışma bulunmaktadır. Başta ABD olmak üzere ağırlıklı olarak gelişmiş ülkeler örnekleminde konunun ele alındığı ampirik literatürde Hamilton'un (1983) çalışması öne çıkmakta, bu çalışmayı takiben gerçekleştirilen diğer çalışmalarda elde edilen bulgularla literatürün zenginleştiği görülmektedir. Hamilton (1983) ABD ekonomisi için 1947-1972 dönemini kapsayan verilerle Granger nedenselliği çerçevesinde gerçekleştirdiği analizde petrol şoklarından gelir, işsizlik oranı ve para arzına doğru tek yönlü nedensellik ilişkilerinin varlığına dair sonuçlara ulaşmıştır. Yazara göre petrol fiyat şokları ve makroekonomik göstergeler arasındaki negatif ilişki tesadüfü ya da herhangi bir üçüncü değişkenin etkisi olmaktan uzaktır. Bu çerçevede yazar petrol fiyatları ile ABD örnekleminde II. Dünya Savaşı sonrası ortaya çıkan durgunluklar arasında sistematik bir ilişki olduğunu savunmaktadır. Burbidge ve Harrison (1984) ise VAR yöntemi kullanarak gerçekleştirdikleri analizde ABD, Ingiltere, Kanada, Almanya ve Japonya gibi gelişmiş ülkeler için 1962-1982 dönemine ait aylık verileri kullanmışlardır. Yazarların analiz bulgularına göre petrol fiyat şokları tüm ülkelerde ücretleri ve fiyatları artırmakta, üretimi ise azaltmaktadır. Fiyat düzeyi üzerindeki etki $A B D$ ve İngiltere'de daha belirgin iken üretim üzerindeki etki ise $A B D$ ve Japonya'da diğer ülkelere göre daha yüksektir. Hamilton'un bulgularının sürekliliğini sorguladığı çalışmasında Hooker (1996) ABD ekonomisi için 1948-1996 yıllarını kapsayan çeyreklik verileri kullandığı çalışmasında ABD makroekonomik verileri ile petrol fiyatları arasındaki ilişkinin 1973 yılına kadar bulunduğu ancak bu yıl sonrasında ilişkinin anlamsızlaştığı sonuçlarına ulaşmıştır.

Literatürde petrol fiyatlarının ekonomi üzerindeki olası asimetrik etkilerinin sorgulandığı çalışmalardan ise Mork (1989), VAR yöntemini kullandığı analizinde ABD ekonomisi için 19491988 yılları arası aylık verilerden yararlanmıştır. Yazar asimetrik etkinin ortaya çıkarabilmesi için fiyat artış ve azalışlarını ayrı seriler olarak modele dâhil etmiş, fiyat artışlarının gelir üzerinde anlamlı negatif etkilerine rağmen fiyat azalışlarının anlamlı bir etkisinin bulunmadığı sonuçlarına ulaşmıştır. Yazar bu bulguyu petrol fiyatları ve iktisadi faaliyet arasındaki ilişkinin asimetrik olduğu şeklinde yorumlamıştır. İlişkinin asimetri bağlamında ele alındığı bir diğer çalışmada ise Ferderer (1996) ABD örnekleminde 1970-1990 dönemini kapsayan analizinde petrol fiyat artışlarının sanayi üretimi üzerindeki etkisinin azalışların etkisinden iki kat daha fazla olduğu sonucuna ulaşmıştır. Ferderer çalışmasında asimetrinin kaynağı olarak ise belirsizliği ve emeğin yeniden dağılım sürecini öne çıkarmaktadır. Asimetrik etkilerin hesaba katıldığı bir diğer çalışmada ise Lardic ve Mignon (2008) 1970-2004 yılları arası verileri kullanarak ABD, G7 ülkeleri ve Euro bölgesi gibi örneklemlerde petrol fiyatlarındaki pozitif değişimlerin etkilerinin negatif değişimlerin etkilerinden daha yüksek olduğu, bu nedenle petrol fiyatları ve gelir arasında asimetrik bir ilişki bulunduğu sonuçlarına ulaşmışlardır. Ordonez vd. (2019) ise İspanya örnekleminde 2000-2014 dönemini kapsayan çeyreklik verileri kullandıkları çalışmalarında 2008 yılı öncesi dönemde petrol fiyat şokları işsizlik oranını azalttığına, 2008 sonrasında ise şoklar karşısında işsizlik oranının arttığına dikkat çekmişlerdir. Çalışma bulgularına göre petrol fiyatlarındaki artışların işsizlik etkisi azalışların etkisinden büyük olduğu için söz konusu dönemde petrol fiyatları ile işsizlik arasında asimetrik bir ilişki bulunmaktadır.

Literatürde petrol fiyatlarının işgücü piyasasındaki etkilerinin araştırıldığı çalışmalardan Loungani (1986), 28 endüstri kolu için 1947-82 yılları arası çeyreklik verileri kullandığı çalışmasında petrol fiyat şoklarının $A B D$ 'de işgücünün yeniden dağılımına neden olmasına 
bağlı olarak bir uyumlanma maliyeti ortaya çıkardığını, bu nedenle işsizliği artırdığını ifade etmiştir. Keane ve Prasad (1996) çalışmalarında petrol fiyat şoklarının toplam ve sanayi kolları özelinde istihdam ve reel ücretler üzerindeki etkilerine yoğunlaşmışlar, iş̧̧ilerin yetkinlik düzeylerinin etkilerini sorgulamışlardır. Bu çerçevede ABD örnekleminde 1966-1981 yıllarını kapsayan çalışmada, panel veri yöntemi kullanılmıştır. Yazarların bulgularına göre petrol fiyat artışları reel ücretleri düşürmekte, istihdamı kısa dönemde düşürürken uzun dönemde etkilememekte, vasıfı iş gücünün istihdam olanaklarını artırmakta, sanayi kolları arasındaki işgücü dağılımını belirlemektedir. Petrol fiyatlarının işgücü piyasasındaki etkilerine yoğunlaşılan bir diğer çalışmada ise Uri (1996), 1947-1995 dönemini kapsayan çalışmasında ABD'de tarımsal işsizliğin petrol fiyatlarından etkilendiğine dair bulgulara ulaşmıştır. Michieka ve Gearhart (2015), ABD'nin Kaliforniya eyaletine bağlı Kern County yerel birimi örnekleminde petrol fiyatlarının yerel istihdam üzerindeki etkilerini inceledikleri çalışmalarında 1990-2015 yılları arası aylık verileri kullanmışlardır. Yazarlar, bölge özelinde petrol fiyatları ile istihdam arasında uzun dönemli bir ilişkinin varlığına rağmen kısa dönemde ise nedensellik bulunmadığını işaret eden sonuçları sunmuşlardır. Kandemir Kocaaslan'ın (2019) 1974-2017 yılları arası çeyreklik verileri kullandığı çalışmasına göre ise ABD'de petrol fiyatlarındaki belirsizlik işsizliği artırmaktadır. Çalışmada ayrıca pozitif petrol şoklarının işsizlik üzerindeki etkisinin negatif şokların etkisinden büyük olduğu ve bu etkinin belirsizlik arttıkça daha da büyüdüğüne dair kanıtlar elde edilmiştir.

Petrol fiyatlarının ekonomik etkilerinin gelişmekte olan ülkeler örnekleminde incelendiği çalışmalardan Papapetrou (2001) VAR yönteminden yararlanmıştır. Yunanistan ekonomisi için aylık verilerin kullanıldığı ve 1989-1999 yıllarını kapsayan çalışmada, petrol fiyat şoklarının sanayi üretimi ve sanayi istihdamındaki dalgalanmaları önemli ölçüde açıkladığı tespit edilmiştir. Tang vd. (2010) ise 1998-2008 yılları arası aylık verileri kullanarak Çin için gerçekleştirdiği çalışmasında ARDL yönteminden yararlanmışlardır. Yazarlar petrol fiyatlarından üretici fiyatlarına doğru bir etkinin varlığının tespiti ile petrol fiyatlarının kısa dönemde üretim maliyetlerini artırdığına dikkat çekmişlerdir. Maliyet artışlarının yatırımların beklenen karlıı̆̆ını düşürdüğüne vurgu yapılan çalışmada yazarlar uzun dönemde petrol şoklarının üretim üzerinde negatif etkileri bulunduğu sonucuna ulaşmışlardır.

Diğer gelişmekte olan ülkelerden farklı olarak ilişkinin petrol üreticisi bir gelişmekte olan ülke olan Libya örnekleminde sorgulandığı çalışmada Yahia ve Saleh (2008), regresyon ve eşbütünleşme analizleri yardımı ile 1970-2005 yılları arasında genel olarak petrol fiyatlarındaki artışların yerel istihdamı artırdığına, 1983-1993 arası durgunluk yıllarında ise istihdamı azalttığına dair sonuçlar elde etmişlerdir. Petrol üreticisi bir diğer gelişmekte olan ülke olan Suudi Arabistan örnekleminde gerçekleştirilen çalışmada ise Alkhateeb vd. (2017) petrol fiyatlarındaki pozitif değişimlerin istihdam artırıcı etkilerinin negatif etkilere göre daha baskın olduğu, bu nedenle ilişkinin asimetrik olduğu sonuçlarına ulaşmışlardır.

Petrol fiyatlarındaki değişimlerin Türkiye ekonomisi üzerindeki etkilerinin araştırıldığı öne çıkan çalışmalardan Torul ve Alper (2010), 1991-2007 dönemini kapsayan analizlerinde VAR yönteminden yararlanmışladır. Yazarların bulgularına göre petrol ürünleri fiyatları, toplam sanayi üretimini ya da özel olarak imalat sanayii üretimini anlamlı bir şekilde etkilemezken ahşap ürünleri, kimyasal ürünler, plastik ürünleri gibi bir takım alt sektörlerde üretim üzerinde etkilere sahiptir. Yazarların bulgularına göre elektronik aletler, radyo-televizyon ve iletişim cihazları sektörleri üretimi üzerinde petrol fiyatlarının asimetrik etkisi bulunmaktadır. Doğrul ve Soytaş (2010) ise 2005-2009 dönemini kapsayan aylık verilerle gerçekleştirdikleri 
nedensellik analizlerinde petrol fiyatlarından işsizlik oranına ve faiz oranına doğru tek yönlü nedenselliğin varlığına dair kanıtları ulaşmışlardır. Benzer şekilde Erkan vd. (2011), aynı dönemi kapsayan çalışmalarında Türkiye'de petrol fiyatlarından işsizlik oranlarına doğru tek yönlü nedenselliğin varlığına dair kanıtlara ulaşılmıştır. Altay vd. (2013) petrol fiyatları ve istihdam ilişkisini ARDL ve VECM yöntemleri ile sorguladıkları çalışmalarında 2000-2012 dönemini kapsayan çeyreklik verilerden yararlanmışladır. Yazarların bulgularına göre eşbütünleşik olduğu tespit edilen seriler arasında kısa dönemde petrol fiyatlarından üretim ve istihdama doğru, uzun dönemde ise yalnızca üretime doğru bir nedensellik ilişkisi bulunmaktadır. Yardımcıoğlu ve Beşel (2013)'in bulgularına göre ise yapısal kırılmaların varlığı altında petrol fiyatları ve işsizlik arasında bir eşbütünleşme ilişkisi bulunmamakta, petrol fiyatlarından işsizliğe doğru tek yönlü bir nedensellik ilişkisi bulunmaktadır. Yılancı (2017) ise 1990-2016 yıllarını kapsayan çalışmasında Fourier tipi eşbütünleşme testinden yararlanmış, analize konu dönemde Türkiye'de petrol fiyatlarındaki ani değişimlerle sanayi üretimi arasında uzun dönemli bir ilişki bulunmadığı sonucuna ulaşmıştır. Çalışmalarında petrol ithalatçısı iki ülke olan Ürdün ve Türkiye'yi ele alan Maghyereh vd. (2019) ise 1986-2014 yılları arası aylık verileri kullanarak her iki ülke için de petrol fiyatları belirsizliğinin sanayi üretimini negatif etkilediği yönünde bulgulara ulaşmışlardır. Yazarlara göre beklenmeyen fiyat şokları artış ya da azalış olmalarından bağımsız olarak sanayi üretimini negatif olarak etkilemektedir.

\section{Veri, Yöntem ve Bulgular}

Çalışmanın bu bölümünde petrol fiyat şoklarının istihdam üzerindeki asimetrik etkileri zaman serileri kullanılarak analiz edilmiştir. Bu çerçevede, reel petrol fiyatlarının yanı sıra petrol kullanımı yoğunluğu görece yüksek olan sanayi sektörü istihdamı verilerinden yararlanılan analizde bir takım kontrol ve kukla değişkenlerine de yer verilmiştir.

\subsection{Veri}

Çalışmanın analiz bölümünde petrol fiyatlarının sanayi istihdamı üzerindeki asimetrik etkileri NARDL yaklaşımıyla araştırılmıştır. Bu çerçevede sanayi istihdamının bağımlı değişken olarak yer aldığı modelde petrol fiyatlarındaki kümülatif artışlar ve azalışlar şeklinde tanımlanmış pozitif ve negatif petrol fiyatı değişimlerinin yanı sıra kontrol değişkeni olarak çalışma çağındaki kurumsal olmayan nüfusa yer verilmiş, bu sayede istihdam edilenlerin sayısındaki nüfus artışının potansiyel etkisi kontrol edilmek istenmiştir. Serilerin zaman içerisindeki eğilimleri Şekil 1'de gösterilmiştir. 
Şekil 1: Serilerin Zamana Bağlı Eğilimleri

InOIL

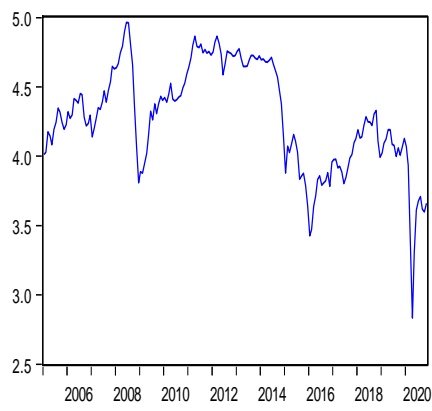

InOIL_neg

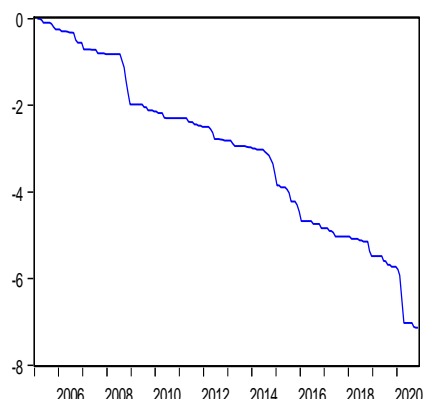

$\operatorname{lnEMP}$
InOIL_pos

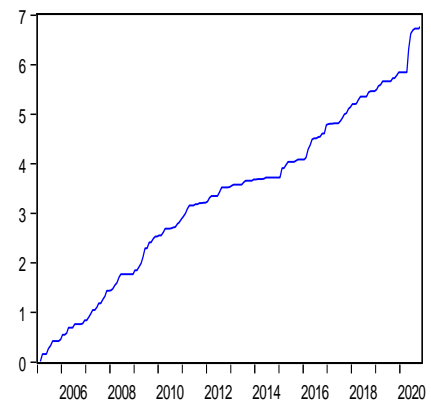

$\ln P O P$
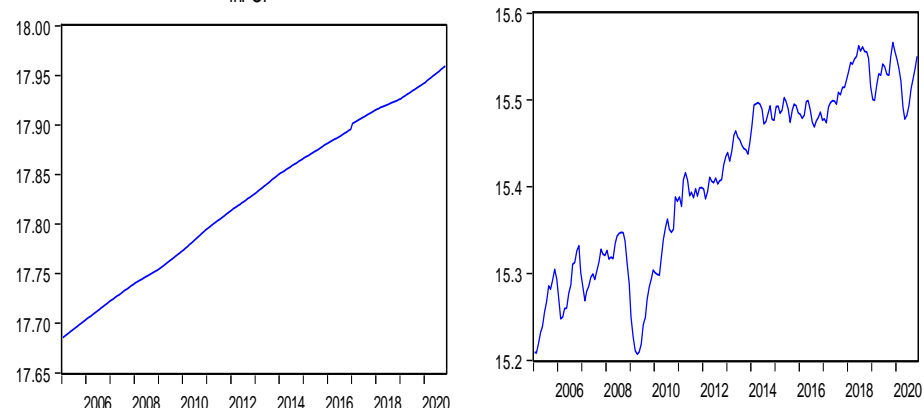

Şekil 1'de InOil_pos ve InOil_neg reel petrol fiyatlarındaki belirli bir başlangıç gözleminden itibaren ortaya çıkan artış ve azalışların birikimli olarak toplanması ile elde edilen sırasıyla pozitif ve negatif petrol fiyat şoklarını ifade etmektedir. Bu çerçevede okuma tersten gerçekleştirildiğinde ise petrol fiyatlarının belirli bir zamandaki değeri, başlangıç değerinden itibaren kendi pozitif ve negatif şoklarının toplamı olarak ifade edilebilecektir.

Şekil 1'de petrol fiyatlarının (InOIL) zaman içerisindeki eğilimi incelendiğinde, büyüklüğün son derece dalgalı bir eğilim içerisinde olduğu, fiyat düşüşlerinin ani ve hızlı artışların ise görece daha yumuşak ve zamana yayılmış olarak gerçekleştiği görülmektedir. Analiz dönemi içerisinde yer alan 2008 yılı küresel finansal krizi ve 2010'lı yıllardaki Arap Baharı gibi gelişmelerin ise petrol fiyatlarındaki dalgalanmaları artırdıkları gözlemlenmektedir. Sanayi istihdamı (InEMP) ise zaman içerisinde bir artış trendinin etkisinde olsa da dalgalı bir seyir izlemektedir. Bu büyüklükte Türkiye'de 2009 yılından itibaren etkileri hissedilmeye başlayan küresel finansal krizin etkileri bu yıldaki dramatik düşüş ile kendini göstermekte, sonrası süreçte ise kısa dönemli dalgalanmalarla birlikte bir artış trendi göze çarpmaktadır. Çalışma çağındaki kurumsal olmayan nüfus (InPOP) değişkenine ait gözlemler ise bu büyüklükte zaman içerisinde toplam nüfus artışı ile uyumlu sabit bir artış trendinin varlığını ortaya koymaktadır. Serilere ilişkin tanımlayıcı istatistikler ekte gösterilmiştir.

Analizde modele pandemi sürecinin istihdam üzerindeki etkilerini üzerinde toplaması amacıyla 2020 yılı Mart ayı ve sonrası 1 değerini almak üzere tanımlanmış olan kukla değişken deterministik olarak eklenmiştir. Bu çerçevede petrol fiyatlarının asimetrik, çalışma çağındaki kurumsal olmayan nüfusun ise simetrik olarak ele alındığı model şu şekilde ifade edilebilecektir: 


$$
\ln E M P=f\left(\ln O I L^{+}, \ln O I L^{-}, \ln P O P\right)
$$

Eşitlikte $\operatorname{lnEMP}$ sanayi sektöründe istihdam edilenlerin logaritması, $\ln P O P$ ise çalışma çağındaki kurumsal olmayan nüfusun logaritması olup TÜiK'in yayınladığı mevsim etkisinden arındırılmış büyüklüklerden oluşmaktadır. Petrol fiyatları, EIA (U.S. Energy Information Administration) verilerinden elde edilen brent petrol varil fiyatlarıdır. ABD doları cinsinden nominal petrol fiyatlarına ait gözlemlerden oluşan seri OECD'den veri tabanından elde edilen ABD tüketici fiyatları endeksi kullanılarak reelleştirilmiştir. $\operatorname{lnO} \mathrm{LL}^{+}$ve $\operatorname{lnOIL^{-}}$ ise logaritması alınmış brent petrol varil fiyatındaki pozitif ve negatif şokları ifade etmektedir. Tüm serilerin doğal logaritmalarının alınmasıyla hem elde edilecek olan katsayılarının yüzde değişim cinsinden yorumlanabilmesi amaçlanmış hem de nüfus ve istihdam edilenlerin sayısı gibi gözlem değerleri yüksek büyüklüklerin tanım aralıkları düşürülerek bireysel gözlemlerin seri ortalamalarına yaklaşması sağlanmıştır. Seriler aylık frekansta erişilebilen en geniş zaman aralığını kapsamak üzere 2005 Ocak - 2020 Kasım dönemi gözlemlerinden oluşmaktadır.

\section{2. Yöntem}

Petrol fiyatlarının sanayi istihdamı üzerindeki asimetrik etkilerinin incelendiği analiz doğrusal olmayan gecikmesi dağıtılmış otoregresif (NARDL) model yardımıyla gerçekleştirilmiştir. Pesaran vd. (2001) hata düzeltme tabanlı geleneksel eşbütünleşme testlerinden (Engle ve Granger, 1987; Johansen, 1988 vb.) farklı olarak analize konu serilerin tamamının birinci seviyelerinde durağan olma koşulunu esnettikleri, sınır testine dayalı bir eşbütünleşme yaklaşımı önermişlerdir. Gecikmesi dağıtılmış otoregresif (ARDL) model olarak tanımlanan bu yaklaşıma göre uzun dönem ilişkisi araştırılacak olan değişkenlerin durağanlıkları; seviyelerinde I(0), birinci farklarında I(1) ya da I(0) ve I(1) kombinasyonu şeklinde olabileceklerdir. Diğer eşbütünleşme testlerine göre küçük örneklemlerin analizinde daha tutarlı sonuçları ortaya koyan ARDL yaklaşımı ile gerçekleştirilen eşbütünleşme testlerinde, serilere ait uzun ve kısa dönem dinamikleri aynı model içerisinde kullanıldığından bu yaklaşım ile elde edilen tahmincilerin daha fazla bilgi içerdiği de ifade edilmektedir (Nusair, 2017:6). Sağladığı bu avantajlar nedeniyle ARDL yaklaşımı zaman serilerinin analizinde ilgi odağı haline gelmiş ve literatürde sık kullanılır bir yöntem olarak yer edinmiştir. NARDL yaklaşımına dayalı asimetrik eşbütünleşme yöntemi ise Shin vd. (2014) tarafından Pesaran vd. (2001)'in önerdiği ARDL yaklaşımındaki doğrusallık varsayımının esnetilmesiyle oluşturulmuştur. Durağanlık koşulları, örneklem büyüklüğüne bağı tahminci etkinliği ve içerdiği bilgi bakımlarından ARDL modelinin avantajlarını barındıran NARDL yaklaşımında açıklayıcı değişken kendi başlangıç değerlerinin, pozitif ve negatif bileşenlerinin toplamı olarak şu şekilde ifade edilmektedir:

$$
x_{t}=x_{0}+x_{t}^{+}+x_{t}^{-}
$$

Eşitlikte $x_{t}^{+}$ve $x_{t}^{-}$şeklinde gösterilen pozitif ve negatif bileşenler ise değişkendeki artış ve azalışların kümülatif toplamları olarak şu şekilde hesaplanmaktadır (Shin vd., 2014:285):

$$
\begin{aligned}
& x_{t}^{+}=\sum_{j=1}^{t} \Delta x_{j}^{+}=\sum_{j=1}^{t} \max \left(\Delta x_{j}, 0\right) \\
& x_{t}^{-}=\sum_{j=1}^{t} \Delta x_{j}^{-}=\sum_{j=1}^{t} \min \left(\Delta x_{j}, 0\right)
\end{aligned}
$$

Bu çerçevede NARDL yaklaşımına göre iki değişken arasında varlığı araştırılacak olan uzun dönem asimetrik ilişkiyi ise şu şekilde ifade etmek mümkündür:

$$
y_{t}=\beta_{0}+\beta^{+} x_{t}^{+}+\beta^{-} x_{t}^{-}+\epsilon_{t}
$$


NARDL yaklaşımında (4) ile gösterilen uzun dönemli asimetrik ilişkinin varlığının sorgulanacağı kısıtsız hata düzeltme modeli (UECM) ise değişkenlere ait uzun dönem ve kısa dönem bilgilerini de içermek üzere şu şekilde gösterilmektedir:

$$
\begin{aligned}
\Delta y_{t}= & a_{0}+\rho y_{t-1}+\theta^{+} x_{t-1}^{+}+\theta^{-} x_{t-1}^{-}+\gamma z_{t}+\sum_{i=1}^{p-1} \beta_{i} \Delta y_{t-j} \\
& +\sum_{i=0}^{q-1}\left(\delta_{i}^{+} \Delta x_{t-i}^{+}+\delta_{i}^{-} \Delta x_{t-i}^{-}\right)+\epsilon_{t}
\end{aligned}
$$

Yaklaşıma göre (5) numaralı eşitlikle gösterilen UECM'nin tahmin edilmesi ve diagnostik kontrollerinin ardından gerçekleştirilecek olan sınır testinde $\rho=\theta^{+}=\theta^{-}=0$ boş hipotezi katsayıların anlamsız olmaması alternatifi karşısında sorgulanacak, elde edilecek olan $\mathrm{F}$ istatistik değeri Pesaran vd. (2001)'in kritik değerleriyle karşılaştırılarak eşbütünleşmenin varlığı hakkında karar verilecektir. Sınır testinde boş hipotezin reddi yani seriler arasında eşbütünleşme ilişkisinin varlığının tespiti halinde ise UECM'den elde edilecek olan katsayılar kullanılarak $\beta_{0}=-a_{0} / \rho, \beta^{+}=-\theta^{+} / \rho$ ve $\beta^{-}=-\theta^{-} / \rho$ işlemleri ile uzun dönem katsayılar elde edilecektir.

NARDL yaklaşımında seriler arasında uzun ve kısa dönemde asimetrik ilişkinin varlığına ise UECM'deki uzun ve kısa dönemde pozitif ve negatif bileşenlerin katsayılarının birbirlerine eşit olup olmadığının Wald testi ile sorgulanmasıyla karar verilmektedir. Buna göre uzun dönem asimetrinin varlığı (5) numaralı denklemde $\theta^{+}=\theta^{-}$koşulunun testiyle, kısa dönem asimetri ise aynı denklemde kısa dönem pozitif ve negatif bileşenlere ait katsayılar toplamlarının birbirlerine eşit olması koşulunun testi $\left(\sum_{i=0}^{q-1} \delta_{i}^{+}=\sum_{i=0}^{q-1} \delta_{i}^{-}\right)$ile belirlenebilmektedir (Katrakilidis ve Trachanas, 2012:1066). Her iki testte de boş hipotezin reddedilmesi asimetri varsayımının geçerliliğini göstermektedir.

Belirli bir hata düzeltme mekanizmasının tanımlanmadığı NARDL yaklaşımının son aşamasında ise pozitif ve negatif bileşenlerin kısa ve uzun dönemde bağımlı değişken üzerindeki etkilerinin görselleştirilmesi amacıyla kümülatif dinamik çarpanlar şu şekilde hesaplanmaktadır (Shin vd., 2014:292).

$$
m_{h}^{+}=\sum_{j=0}^{h} \frac{\partial y_{t+j}}{\partial x_{t}^{+}} \text {ve } m_{h}^{-}=\sum_{j=0}^{h} \frac{\partial y_{t+j}}{\partial x_{t}^{-}} \quad \text { iken } h=0,1,2 \ldots
$$

Hesaplanan pozitif ve negatif kümülatif dinamik çarpan değerlerinin ise ( $m_{h}^{+}$ve $\left.m_{h}^{-}\right)$ $h$ sonsuza yaklaştıkça uzun dönem katsayılara $\left(\beta^{+}\right.$ve $\left.\beta^{-}\right)$yakınsadığı bilinmektedir. Asimetrik dinamik çarpanların hesaplanması ve görselleştirilmesi ile serilerin kısa dönemli hareketleri ve uzun dönem uyum patikalarının yanı sıra varsa dengesizliklerin ortadan kalkma süreci hakkında bilgi sağlanabilmektedir.

\subsection{Bulgular}

ARDL yaklaşımı ile paralel biçimde NARDL modellerinde de analize tabi tutulan serilerin düzeyde ya da birinci farklarında durağan olmaları, herhangi birinin ikinci farkında durağan olmaması gerekmektedir (Fousekis vd., 2016: 500). Bu nedenle analiz öncesinde serilerin durağanlık düzeyleri belirlenmelidir. Çalışmada serilerin durağanlık düzeylerinin belirlenmesi için doğrusal testler olan ADF (Genelleştirilmiş Dickey-Fuller) ve bir yapısal kırılmanın varlığı altında durağanlığın sınandığı ZA (Zivot-Andrews) testlerinin yanı sıra Fourier ADF (FADF) birim kök testinden yararlanılmıştır. Enders ve Lee (2012) tarafından önerilen FADF testi ile sayısı, tarihi ve niteliği/formu belirsiz olmak üzere çoklu kırılmaların varlığı koşullarında diğer sınırlı sayıda kırılmaları baz alan testlere göre daha etkin sonuçlar edilmektedir. Bilinmeyen sayıda ve nitelikte kırılmalara karşı etkinliğinin yanı sıra bu çalışmada FADF testinden 
yararlanıımasının bir diğer nedeni de testin doğrusalsızlığa dayalı yapısının çalışmada kullanılan yöntemle uyumlu olmasıdır.

ADF ve ZA testlerine ait bulgular Tablo 2'de, FADF testi bulguları ise Tablo 3'te gösterilmiştir.

Tablo 2: ADF ve ZA Birim Kök Testleri Bulguları

\begin{tabular}{|c|c|c|c|c|c|c|}
\hline \multirow[b]{3}{*}{ Değişkenler } & \multicolumn{2}{|c|}{ ADF } & \multicolumn{4}{|c|}{ ZA } \\
\hline & \multirow{2}{*}{$\begin{array}{c}\text { Sabitli } \\
\text { Test İst. }\end{array}$} & \multirow{2}{*}{$\frac{\text { Sabitli \& Trendli }}{\text { Test İst. }}$} & \multicolumn{2}{|c|}{ Sabitte Kırılma } & \multicolumn{2}{|c|}{$\begin{array}{c}\text { Sabitte ve Trendde } \\
\text { Kırılma }\end{array}$} \\
\hline & & & Test İst. & Kırılma & Test İst. & Kırılma \\
\hline InEMP & $-1.635(1)$ & $-3.723 * *(1)$ & $-3.980(7)$ & $2010 \mathrm{M} 10$ & $-4.153(7)$ & $2010 \mathrm{M} 10$ \\
\hline InOIL & $-2.604 *(1)$ & $-3.349 *(1)$ & $-4.287(2)$ & 2014M10 & $-4.371(2)$ & 2014M10 \\
\hline $\ln P O P$ & $-2.040(1)$ & $-0.877(1)$ & $-4.099(3)$ & $2017 \mathrm{M} 2$ & $-3.164(3)$ & 2010M1 \\
\hline$\Delta \operatorname{lnEMP}$ & $-7.393 * * *(5)$ & $-7.364 * * *(5)$ & $-7.102 * * *(8)$ & 2009M9 & $-7.383^{* * *}(8)$ & 2009M9 \\
\hline$\Delta \operatorname{lnOIL}$ & $-9.708 * * *(1)$ & $-9.717^{* * *}(1)$ & $-9.947 * * *(1)$ & $2016 \mathrm{M} 2$ & $-9.977 * * *(1)$ & $2016 \mathrm{M} 2$ \\
\hline$\Delta \operatorname{lnPOP}$ & $-6.874 * * *(1)$ & $-10.721 * * *(0)$ & $-5.790 * * *(2)$ & $2009 \mathrm{M} 2$ & $-6.437 * * *(2)$ & 2018M1 \\
\hline
\end{tabular}

Notlar: $\Delta$ fark operatörüdür. ${ }^{*},{ }^{* *}$ ve ${ }^{* * *}$ sırasıyla $\% 10,5$ ve 1 düzeyde serilerin durağan olduklarını göstermektedir. Parantez içerisindeki sayılar gecikme uzunluklarıdır. ZA testinden elde edilen test istatistikleri Zivot ve Andrews (1992) kritik değerleri ile karşılaştırılmıştır. Sabitte kırılmanın varsayıldığı modelde kritik değerleri \% 1, 5 ve 10 düzeylerde sırasıyla $-5.34,-4.93,-4.58$; sabitte ve trendde kırılmanın varsayıldığı modelde kritik değerleri ise aynı sırayla -5.57, 5.08 ve -4.82 'dir.

ADF testi ve ZA testi bulguları tekil modellerde ve düşük anlamlılık düzeyinde bazı serilerin seviyelerinde durağan olduklarına dair bulguları sunmakta ancak genel ifadeyle serilerin birinci farklarında durağanlıklarının sağlandığını göstermektedir.

Tablo 3: FADF Birim Kök Testi Bulguları

\begin{tabular}{|c|c|c|c|c|c|c|c|c|c|c|}
\hline \multirow[b]{3}{*}{ Değişken } & \multicolumn{5}{|c|}{ Model 1} & & & \multicolumn{3}{|c|}{ Model 2} \\
\hline & \multicolumn{5}{|c|}{ Kritik Değerler } & & & \multicolumn{3}{|c|}{ Kritik Değerler } \\
\hline & $\mathrm{k}$ & FADF ist. & $1 \%$ & $5 \%$ & $10 \%$ & $\mathrm{k}$ & FADF ist. & $1 \%$ & $5 \%$ & $10 \%$ \\
\hline InOIL & 3 & $-2.329(2)$ & -3.74 & -3.06 & -2.72 & 3 & $-2.992(2)$ & -4.38 & -3.77 & -3.43 \\
\hline InEMP & 4 & $-0.723(6)$ & -3.62 & -2.98 & -2.65 & 1 & $-3.617(7)$ & -4.87 & -4.31 & -4.02 \\
\hline $\ln P O P$ & 5 & $-2.963 * *(1)$ & -3.55 & -2.94 & -2.62 & 1 & $-3.625(1)$ & -4.84 & -4.31 & -4.02 \\
\hline$\Delta \operatorname{lnOIL}$ & 3 & $-9.849 * * *(1)$ & -3.74 & -3.06 & -2.72 & 3 & $-9.838 * * *(1)$ & -4.38 & -3.77 & -3.43 \\
\hline$\Delta \ln E M P$ & 4 & $-6.581 * * *(8)$ & -3.62 & -2.98 & -2.65 & 4 & $-6.545 * * *(8)$ & -4.27 & -3.63 & -3.31 \\
\hline$\triangle \operatorname{lnPOP}$ & 5 & $-7.710 * * *(1)$ & -3.55 & -2.94 & -2.62 & 5 & $-12.638 * * *(0)$ & -4.18 & -3.56 & -3.24 \\
\hline
\end{tabular}

Notlar: $\Delta$ fark operatörüdür. ${ }^{*}, * *$ ve ${ }^{* * *}$ sırasıyla $\% 10,5$ ve 1 düzeyde serilerin durağan olduklarını göstermektedir. Model 1 sabitli, Model 2 sabitli ve trendli modelleri ifade etmektedir. Parantez içerisindeki sayılar $t$ istatistiğine göre belirlenen gecikme uzunlukları, $k$ ise frekans sayılarıdır. Maksimum gecikme uzunluğu 12, maksimum frekans sayısı ise 5 olarak belirlenmiştir. Kritik değerler Enders ve Lee'den (2012) elde edilmiştir.

Tablo 3'te özetlenen doğrusal olmayan ve çoklu kırılmaları modele dâhil eden FADF testi bulguları da doğrusal birim kök testleri bulguları tutarlılık göstermektedir. Test bulgularına göre serilerinin tamamı birinci farklarının alınmasıyla durağan hale gelmektedirler. Elde edilen bulgular söz konusu serilerin NARDL analizine dâhil edilebileceğini ortaya koymaktadır. Bu çerçevede NARDL yaklaşımı ile değişkenler arasında varlığı araştırılan uzun dönem ilişki (4) numaralı eşitlikte analize konu değişkenler kullanılarak şu şekilde ifade edilebilir:

$$
\ln E M P_{t}=\alpha_{0}+\alpha_{1} \operatorname{lnOIL}_{t}{ }^{+}+\alpha_{2} \operatorname{lnOIL}_{t}{ }^{-}+\alpha_{3} \ln P O P+\varepsilon_{t}
$$

Eşitlikte $\operatorname{lnOIL}_{t}{ }^{+}$ve $\operatorname{lnOIL}_{t}{ }^{-}$logaritmik petrol fiyatları serisinin pozitif ve negatif bileşenlerini göstermektedir. Modele ayrıca dünyada 2019 yılı sonunda ortaya çıkan ve Türkiye'de varlığı 2020 yılı Mart ayında tespit edilen COVID-19 virüsüne dayalı küresel salgın 
koşullarının istihdam üzerindeki potansiyel etkilerini üzerinde toplaması amacıyla 2020 yılı Mart ayı ve sonrasında 1 diğer değeri alan kukla değişken eklenmiştir. Bu çerçevede oluşturulan ve uzun dönem ilişkinin açığa çıkarılması için tahmin edilecek olan UECM modeli ise şu şekildedir:

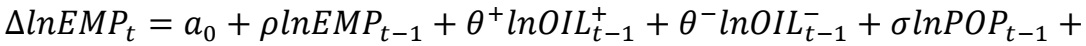

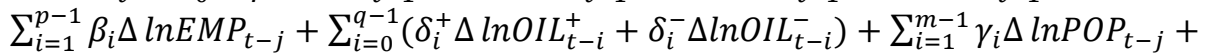

$$
\begin{aligned}
& D U M+\epsilon_{t}
\end{aligned}
$$

Örneklem büyüklüğü göz önünde bulundurularak 18'e kadar gecikme ile tahmin edilmiş olan UECM'de Shin vd. (2014) takip edilerek, belirli bir düzeyde anlamlılı̆ı ve modele açıklayıcılık bakımından katkısı bulunmayan gecikmeler model dışı bırakılmıştır. Bu sayede tahmin edilen model, anlamsız gecikmelerin varlığı ile ortaya çıkabilecek olan aşırı parametrize model problemi ve dinamik kararsızlıklardan da arındırılmıştır (Katrakilidis ve Trachanas, 2012: 1067; Fousekis vd. 2016: 502). NARDL yaklaşımı ile tahmin edilen UECM bulguları Tablo 4'te özetlenmiştir.

Tablo 4: UECM Tahmin Sonuçları

\begin{tabular}{|c|c|c|c|}
\hline \multicolumn{4}{|c|}{ Bağımlı Değişken: $\Delta \ln E M P$} \\
\hline Değişken & Katsayı & $\mathrm{t}$ - istatistik & Olasılık \\
\hline Sabit & $-6.206 * * *$ & -4.300 & 0.000 \\
\hline $\ln E M P_{t-1}$ & $-0.238 * * *$ & -5.970 & 0.000 \\
\hline $\operatorname{lnOI} L_{t-1}^{+}$ & $-0.008^{*}$ & -1.948 & 0.053 \\
\hline $\operatorname{lnOI} L_{t-1}^{-}$ & $0.012^{* * *}$ & 3.418 & 0.001 \\
\hline $\ln P O P_{t-1}$ & $0.759 * * *$ & 4.766 & 0.000 \\
\hline$\Delta \ln E M P_{t-1}$ & $0.441^{* * *}$ & 6.193 & 0.000 \\
\hline$\Delta \ln E M P_{t-3}$ & $-0.129 * * *$ & -1.840 & 0.068 \\
\hline$\Delta \ln E M P_{t-4}$ & $0.304 * * *$ & 4.242 & 0.000 \\
\hline$\Delta \ln E M P_{t-7}$ & $0.121 *$ & 1.817 & 0.071 \\
\hline$\Delta \ln E M P_{t-12}$ & $0.277^{* * *}$ & 4.633 & 0.000 \\
\hline$\Delta \ln E M P_{t-15}$ & $0.116^{*}$ & 1.813 & 0.072 \\
\hline$\Delta \operatorname{lnOIL} L_{t}^{+}$ & $-0.035^{* *}$ & -2.222 & 0.028 \\
\hline$\Delta \operatorname{lnOI} L_{t-1}^{+}$ & $0.051 * * *$ & 3.337 & 0.001 \\
\hline$\Delta \operatorname{lnOIL} L_{t-6}^{+}$ & $0.026^{*}$ & 1.877 & 0.062 \\
\hline$\Delta \ln O I L_{t-16}^{+}$ & $-0.037 * *$ & -2.158 & 0.033 \\
\hline$\Delta \operatorname{lnOIL} L_{t}^{-}$ & $0.036^{* * *}$ & 3.507 & 0.001 \\
\hline$\Delta \operatorname{lnOIL} L_{t-3}^{-}$ & $0.027^{* *}$ & 2.437 & 0.016 \\
\hline$\Delta \ln P O P_{t-7}$ & $3.217^{*}$ & 1.797 & 0.074 \\
\hline$D U M$ & 0.007 & 1.432 & 0.154 \\
\hline \multicolumn{4}{|l|}{ Sınır Testi } \\
\hline F-istatistik & $\% 99$ Alt sınır & \% 99 Üst sınır & Karar \\
\hline 7.416 & 4.56 & 5.83 & Eşbütünleşme \\
\hline \multicolumn{4}{|c|}{ Uzun ve Kısa Dönem Asimetri Testleri } \\
\hline$W_{L R}$ & $3.724 * * *(0.000)$ & & \\
\hline$W_{S R}$ & $-1.721 *(0.087)$ & & \\
\hline \multicolumn{4}{|c|}{ Uzun Dönem Katsayılar } \\
\hline$\beta_{\text {lnoil }}^{+}$ & $-0.033 * *(0.036)$ & & \\
\hline$\beta_{\text {lnoil }}^{-}$ & $0.052 * * *(0.000)$ & & \\
\hline$\beta_{\text {lnpop }}$ & $3.189 * * *(0.000)$ & & \\
\hline
\end{tabular}




\begin{tabular}{ll}
\hline Model istatistikleri ve Diagnostik Testler & \\
\hline$R^{2}$ & 0.520 \\
$D W$ & 2.073 \\
$S I C$ & -6.168 \\
Jarque - Bera, $\chi^{2}$ ist. & $0.009(0.996)$ \\
Breusch - Godfrey LM $(6,12,18), \chi^{2}$ ist. & $6.811(0.339), 12.479(0.416), 19.413(0.367)$ \\
White, $\chi^{2}$ ist. & $24.405(0.142)$ \\
CUSUM & Kararlı \\
CUSUMQ & Kararlı \\
\hline
\end{tabular}

Notlar: $\Delta$ fark operatörüdür. + ve - üst indisleri pozitif ve negatif birikimli toplam serilerini göstermektedir. $\beta^{+}$ve $\beta^{-}$ uzun dönem asimetrik katsayı tahminleridir. Jarque - Bera, Breusch - Godfrey ve White testlerinden elde edilen $\chi^{2}$ değerleri sırasıyla normallik, otokorelasyon ve heteroskedastisite testlerine ait istatistiklerdir. Parantez içerisindeki değerler olasılık değerlerini göstermektedir. ${ }^{*},{ }^{* *}$ ve ${ }^{* * *}$ sırasıyla $\% 10,5$ ve 1 anlamlılık düzeylerini ifade etmektedir. Sınır testi kritik değerleri Pesaran (2001)'den elde edilmiştir. $W_{L R}$ uzun dönem, $W_{S R}$ kısa dönem asimetri testlerine ait Wald testi $\mathrm{t}$ istatistikleridir. Modelin dinamik kararlılı̆ının test edildiği CUSUM ve CUSUMQ testlerine ait güven aralıkları ekte gösterilmiştir.

Tablo 4'te özetlenen ve NARDL yaklaşımı ile oluşturulmuş UECM kullanılarak gerçekleştirilen sınır testi F istatistiğinin (7.416), Pesaran'dan (2001) elde edilen üst sınırı aştığı görülmektedir. Bu bulgu petrol fiyatlarının asimetrik etkilerinin kabulü altında seriler arasında eşbütünleşme ilişkisinin varlığını ortaya koymaktadır. Diğer bir ifadeyle sınır testi bulgularına göre seriler arasında uzun dönem ilişkisi mevcuttur. Uzun ve kısa dönemde asimetrinin geçerliliğinin sınandığı Wald testi sonuçları ise hem uzun hem de kısa dönemde petrol fiyatlarının sanayi istihdamı üzerinde asimetrik etkilerinin bulunduğunu işaret etmektedir.

Uzun ve kısa dönemde asimetrinin varlığının tespitinin ardından (7) numaralı eşitlikte gösterilen uzun dönem ilişkiye ait katsayılar hesaplanmıştır. Elde edilen değerler pozitif petrol fiyatı değişimlerinin katsayısının (-0.033) negatif, negatif değişimlerin katsayısı (0.052) pozitif olduğunu ortaya koymaktadır. Uzun dönem asimetrik katsayılar petrol fiyatlarındaki ilave pozitif değişimlerin sanayi istihdamını negatif etkilediğini göstermektedir. Diğer taraftan negatif petrol fiyatı değişimlerine ait uzun dönem katsayının pozitif olması, ilave negatif fiyat değişimlerinin istihdam üzerinde yine negatif etkiye yol açtığını göstermektedir. Diğer bir ifadeyle elde edilen uzun dönem katsayılara göre petrol fiyatlarındaki \%1 artış sanayi sektöründe istihdam edilenlerin sayısını \%0.33 azaltırken fiyatların \%1 azalması ise istihdam edenlerin sayısında \%0.52'lik bir azalmaya yol açmaktadır. Çalışma çağındaki kurumsal olmayan nüfus değişkenine ait simetrik katsayı ise beklentiye uygun olarak pozitiftir. 
Şekil 2: Asimetrik Dinamik Çarpanlar

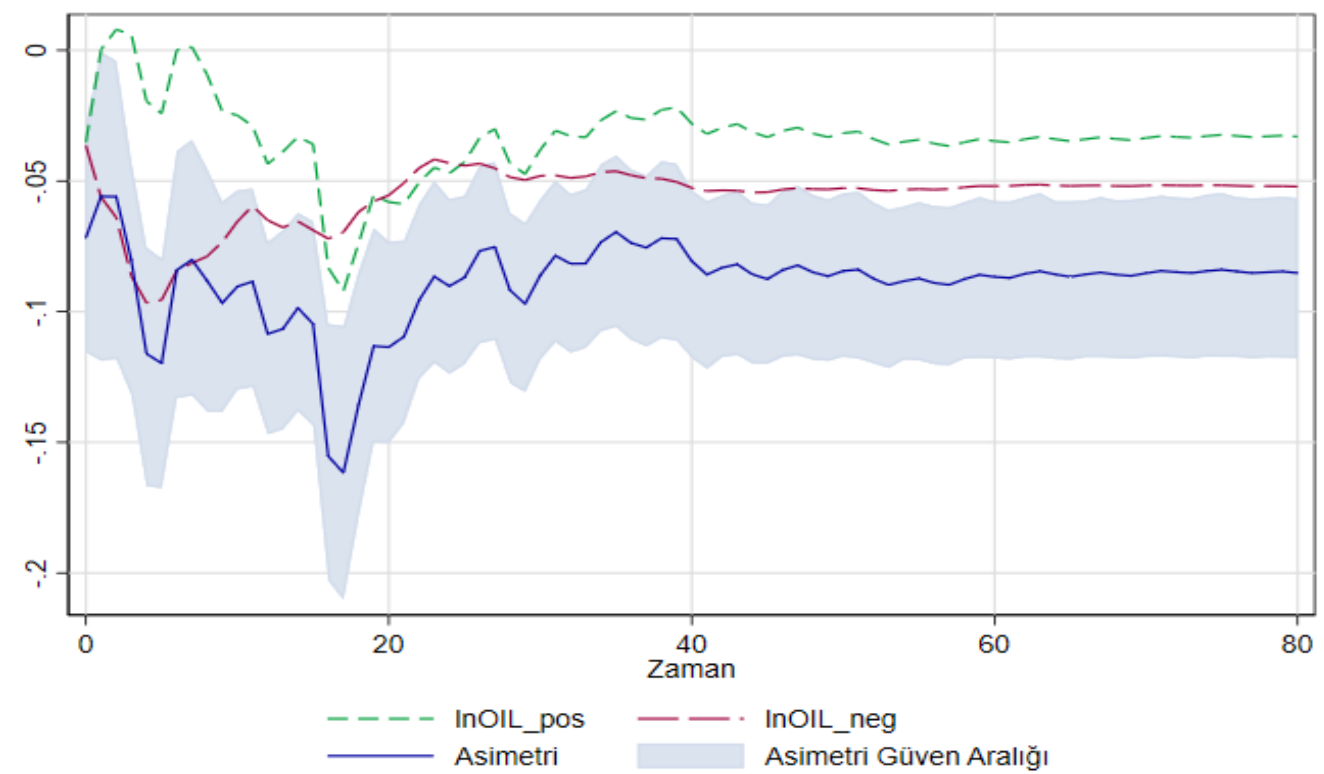

Notlar: \%95 bootstrap güven aralığı 1000 tekrara dayalı olarak türetilmiştir. InOIL_pos ve InOIL_neg sırasıyla pozitif ve negatif petrol fiyat şoklarını ifade etmektedir.

(6) numaralı eşitliğe uygun olarak hesaplanan ve petrol fiyatlarındaki pozitif ve negatif değişimlerin yanı sıra toplam asimetrik etkinin görselleştirildiği kümülatif asimetrik dinamik çarpanlar Şekil 2'de gösterilmektedir. Dinamik çarpanların zaman içerisindeki konumu, gerek pozitif gerekse negatif petrol fiyat şoklarının istihdam üzerinde negatif etkiye sahip olduğun göstermektedir. Dinamik çarpanlara göre kısa dönemdeki dalgalı hareket üçüncü yılın ortalarından itibaren yerini görece daha dengeli bir sürece bırakmaktadır. Bu dönemden itibaren negatif fiyat şoklarının istihdam üzerindeki etkisi daha istikrarlıyken pozitif şokların dalgalı etkisi, toplam asimetrik etkinin görece istikrarlı patikada dahi kısmen dalgalı bir seyir izlemesine yol açmaktadır. Uzun dönemde görece dengeli patikada dahi dalgalanmaların devam etmesi kısa dönem petrol fiyat şoklarının dengesizlikler ortaya çıkaran etkilerinin uzun döneme yansıdığını göstermektedir. Dinamik çarpanlara ait grafik bulguları kısa ve uzun dönem asimetri bulguları ile de tutarlıdır.

Analizde elde edilen bulguların kısa dönem çıkarımları, çalışmalarında petrol fiyatlarından işsizlik oranlarına doğru nedensellik ilişkisinin varlığına dair kanıtlara ulaşan Doğrul ve Soytaş (2010), Erkan vd. (2011) ve Yardımcıoğlu ve Beşel (2013); petrol fiyatlarından istihdama doğru nedenselliğin varlığı sonuçlarını elde eden Altay vd.'nin (2013) bulgularını desteklemektedir. Analizin uzun dönem bulguları ise Türkiye'de petrol fiyatları belirsizliğinin sanayi üretimini negatif etkilediği yönünde kanıtlar sunan Maghyereh vd. (2019) ile tutarlılık göstermektedir.

\section{Tartışma, Sonuç ve Öneriler}

Petrol fiyatlarındaki değişimlerin istihdam üzerindeki etkilerinin incelendiği çalışmada elde edilen bulgular, petrol fiyatlarındaki hem pozitif hem de negatif fiyat şoklarının sanayi istihdamını azalttığını ortaya koymaktadır. Bu bulgu petrol fiyat şoklarının yönünden bağımsız olarak Türkiye'de sanayi istihdamını asimetrik olarak ve negatif etkilediğini göstermektedir. 
Ferderer (1996) petrol fiyatlarının ekonomik aktivite üzerindeki asimetrik etkilerinin ortaya çıkmasında aracılık eden üç kanalı öne çıkarmaktadır. Tablo 1'de geçiş dinamikleri ve beklenen etkileri özetlenen geçiş kanallarından para politikası kanalına göre petrol fiyatı şokları karşısında enflasyon hedeflemesi yapmayan parasal otoritelerin fiyat istikrarını koruma amacıyla para politikası uygulamaması durumunda petrol fiyat şoklarının asimetrik etkileri gözlemlenebilecektir. Ancak Türkiye örnekleminde parasal karar verici olan TCMB'nin analize konu dönemin tamamında enflasyon hedeflemesi ile faaliyet yürütüyor olması, petrol fiyatlarının asimetrik etkilerinin ortaya çıkmasında para politikası kanalını daha az şüpheli hale getirmektedir.

Asimetrinin potansiyel kaynağı olan emeğin yeniden dağılımı kanalına göre petrol fiyatlarındaki değişimler üretimin yapısını değiştirmek suretiyle başta emek olmak üzere üretim faktörlerinin sektörler arası yeniden dağılımına ve friksiyonel bir işsizliğin ortaya çıkmasına yol açabilecektir. Tam istihdam koşullarında ekonomik faaliyet sürdüren gelişmiş ülkelerde, emeğin kârlı sektörlere mobilize olması ve petrol şoklarından negatif etkilenen sektörlerde istihdamın azalması olası bir sonuç iken işsizlik oranların sürekli doğal oranın üzerinde seyrettiği ve hazırda yüksek sayıda yedek işgücünün bulunduğu Türkiye'de ise emeğin yeniden dağılımı kanalı petrol fiyatlarının asimetrik etkisini açıklamakta yeterli bir argüman olmaktan uzaktır.

Çalışmada elde edilen asimetrik etkilerin Türkiye örnekleminde açıklanmasında petrol fiyatları ve reel ekonomik faaliyet arasındaki ilişkiyi açıklayan kanallardan petrol fiyatlarının belirsizliği kanalı öne çıkmaktadır. Petrol fiyatlarının öngörülemezliği şeklinde ortaya çıkan belirsizlik; maliyet koşulları hakkında çıkarımda bulunamayan yatırımcıların yatırımlarını ertelenmesine yol açacak, dolayısıyla üretimi ve istihdamı azaltacaktır. Petrol fiyatlarının belirsizliği mevcut firmaların da fiyatlandırma konusunda belirsizliğe düşmelerine yol açarak üretim ve istihdam üzerinde negatif etkilere sahip olabilecektir. Diğer taraftan fiyat belirsizliğinin yarattığı güvensizlik ortamında yabancı sermaye akışının sürdürülebilirliği için parasal yetkililer daha yüksek faiz oranları tercihinde bulunabilecek, yükselen faizler yatırımları ve üretimi düşürebilecektir. Bu bağlamda petrol fiyatlarındaki pozitif ve negatif şokların belirsizlik kanalıyla sanayi istihdamını olumsuz etkilediği sonuçlarına ulaşılan çalışma bulguları, Maghyereh vd.'nin (2019) Türkiye'de petrol fiyatları belirsizliğinin sanayi üretimini olumsuz etkilediği yönündeki bulguları ile tutarlıdır. Bu çerçevede çalışma bulguları gelecek çalışmalarda petrol fiyat belirsizliğine gösterge seriler kullanılarak belirsizliğin istihdam üzerindeki etkilerine yoğunlaşılması yönünde motivasyon oluşturmaktadır.

Gelişmekte olan ve net petrol ihracatçısı yapısı gereği Türkiye'nin uluslararası petrol fiyatları üzerinde belirleyiciliği olmadığından beklenmeyen fiyat artışları ve azalışları şeklinde ortaya çıkan petrol fiyat şoklarının engellenmesi noktasında da bir tasarruf imkânı bulunmamaktadır. Bu nedenle politik ve ekonomik karar birimlerinin petrol fiyatları şoklarının negatif ekonomik etkilerinin önlenmesi ya da azaltılması konularında petrol fiyat şoklarının reel ekonomik faaliyeti etkilemesinde aracılık eden geçiş kanallarına ve dinamiklerine odaklanması gerekmektedir. Bu çalışmada elde edilen bulgular petrol fiyat şoklarının istihdamı asimetrik olarak ve negatif etkilediğini ortaya koymakta, asimetrinin kaynağı olarak ise belirsizlik kanalını sorumlu tutmaktadır. Belirsizlik, bir taraftan maliyetler ve fiyatlama konularında firmalar ve girişimciler açısından ortaya çıkardığı öngörülemezlik diğer taraftan ise söz konusu öngörülemezliğin yarattığı güvensizlik ortamında yabancı sermaye akımlarının sekteye uğraması gibi nedenlerle üretimin ve istihdamın gerilemesine yol açmaktadır. Bu 
nedenle politik ve ekonomik karar vericilerin petrol fiyatlarındaki dalgalanmaların yüksek olduğu dönemlerde aktif olarak sanayi sektörü başta olmak üzere üreticilerin maliyet istikrarını koruyucu destek ve düzenlemeleri hayata geçirmeleri belirsizliğin negatif etkilerini azaltabilecektir. Diğer taraftan parasal karar vericilerin fiyat istikrarı hedeflemesi yapmadığı koşullarda para politikası kanalının da asimetrik etkilerin hissedilmesinde etkili olduğu savunulmaktadır. Bu çerçevede petrol fiyat şoklarının asimetrik etkilerinin azaltılması ya da derinleştirilmemesi için Türkiye'de parasal otoritenin fiyat istikrarı temel hedefinden sapmaması gerekmektedir. Fiyat istikrarı hedeflemesinde en başarılı performanslara ise araç ve amaç bağımsızlığına sahip merkez bankalarınca ulaşıldığı bilindiğinden asimetrik etkilerin önlenmesi için merkez bankası bağımsızlığından ödün verilmemelidir. 


\section{Kaynakça}

Alkhateeb, T. T. Y.; Mahmood, H.; Sultan, Z. A.; Ahmad, N. (2017), “Oil Price and Employment Nexus in Saudi Arabia", International Journal of Energy Economics and Policy, Vol. 7, No. 3: 277-281.

Altay, B.; Topcu, M.; Erdoğan, E. (2013), "Oil Price, Output and Employment in Turkey: Evidence from vector Error Correction Model", International Journal of Energy Economics and Policy, Vol. 3, Special Issue: 7-13.

Bernanke, B. S.; Gertler, M.; Watson, M. (1997), "Systematic Monetary Policy and the Effects of Oil Price Shocks", Brookings Papers on Economic Activity, 1997 No. 1: 91-157.

Brown, S. P. A.; Yücel, M. K.; Thompson, J. (2003), "Business Cycles: The Role of Energy Prices", Federal Reserve Bank of Dallas Research Department Working Paper 0304.

Burbidge, J.; Harrison, A. (1984), "Testing the Effects of Oil-Price Rises Using Vector Autoregressions", International Economic Review, Vol. 25, No. 2: 459-484.

Doğrul, H. G.; Soytas, U. (2010), "Relationship between Oil Prices, Interest Rate, and Unemployment: Evidence from an Emerging Market", Energy Economics, Vol. 32, No. 6: 1523-1528.

Enders, W.; Lee, J. (2012), "The Flexible Fourier Form and Dickey-Fuller Type Unit Root Tests", Economic Letters, No. 117: 196-199.

Erkan, B.; Şentürk, M.; Akbaş, Y. E.; Bayat, T. (2011), "Uluslararası Ham Petrol Fiyatlarındaki Volatilitenin İşsizlik Göstergeleri Üzerindeki Etkisi: Türkiye Örneği Üzerine Ampirik Bulgular", Gaziantep Üniversitesi Sosyal Bilimler Dergisi, C. 10, S. 2: 715-730.

Ferderer, J. P. (1996), "Oil Price Volatility and the Macroeconomy", Journal of Macroeconomics, Vol. 18, No. 1: 1-26.

Fousekis, P.; Katrakilidis, C.; Trachanas, E. (2016), "Vertical Price Transmission in the US Beef Sector: Evidence from the Nonlinear ARDL Model", Economic Modelling, Vol. 52(B): 499-506.

Gisser, M.; Goodwin, T. H. (1986), "Crude Oil and the Macroeconomy: Tests of Some Popular Notions: Note", Journal of Money, Vol. 18, No. 1: 95-103.

Hamilton, J. D. (1983), "Oil and the Macroeconomy since World War II", Journal of Political Economy, Vol. 91, No. 2: 228-248.

Hooker, M. A. (1996), "What Happened to the Oil Price-Macroeconomy Relationship?", Journal of Monetary Economics, Vol. 38, No. 2: 195-213.

Kandemir Kocaaslan, O. (2019), "Oil Price Uncertainty and Unemployment", Energy Economics, Vol. 81(C): 577-583.

Katrakilidis, C.; Trachanas, E. (2012), "What Drives Housing Price Dynamics in Greece: New Evidence from Asymmetric ARDL Cointegration", Economic Modelling, Vol. 29, No. 4: 1064-1069.

Keane, M. P.; Prasad, E. S. (1996), "The Employment and Wage Effects of Oil Price Changes: A Sectoral Analysis", The Review of Economics and Statistics, Vol. 78, No. 3: 389-400.

Lardic, S.; Mignon, V. (2008), "Oil Prices and Economic Activity: An Asymmetric Cointegration Approach", Energy Economics, Vol. 30, No. 3: 847-855.

Loungani, P. (1986), "Oil Price Shocks and the Dispersion Hypothesis", The Review of Economics and Statistics, Vol. 68, No. 3: 536-539.

Maghyereh, A. I.; Awartani, B.; Sweidan, O. D. (2019), "Oil Price Uncertainty and Real Output Growth: New Evidence from Selected Oil-Importing Countries in the Middle East", Empirical Economics. No. 56: 1601-1621.

Michieka, N. M.; Gearhart, R. (2015), "Oil Price Fluctuations and Employment in Kern County: A Vector Error Correction Approach", Energy Policy, No. 87: 584-590. 
Mork, K. A. (1989), "Oil and the Macroeconomy when Prices Go Up and Down: An Extension of Hamilton's Results", Journal of Political Economy, Vol. 97, No. 3: 740-744.

Mork, K. A. (1994), "Business Cycles and the Oil Market", The Energy Journal, Vol. 15, Special Issue on the Changing World Petroleum Market: 15-38.

Mussa, M. (2000), "The Impact of Higher Oil Prices on the Global Economy", https://www.imf.org/external/pubs/ft/oil/2000/oilrep.PDF, (Erişim: 19.12.2020).

Nusair, S. A. (2017), "The J-Curve Phenomenon in European Transition Economies: A Nonlinear ARDL Approach", International Review of Applied Economics, Vol. 31, No. 1: 1-27.

Ordonez, J.; Monfort, M.; Cuestas, J. C. (2019), "Oil Prices, Unemployment and the Financial Crisis in Oil-Importing Countries: The Case of Spain", Energy, No. 181: 625-634.

Papapetrou, E. (2001), "Oil Price Shocks, Stock Market, Economic Activity and Employment in Greece", Energy Economics, Vol. 23, No. 5: 511-532.

Pesaran, M. H.; Shin, Y.; Smith, R. J. (2001), "Bound Testing Approaches to the Analysis of Level Relationships", Journal of Applied Econometrics, No. 16: 289-326.

Shin, Y.; Yu, B.; Greenwood-Nimmo, M. (2014), "Modelling Asymmetric Cointegration and Dynamic Multipliers in a Nonlinear ARDL Framework. Festschrift in Honor of Peter Schmidt: Econometric Methods and Applications (Eds. W. C. Horrace and R. C. Sickles), Springer: New York: 281-314.

Tang, W.; Wu, L.; Zhang, ZX. (2010), "Oil Price Shocks and Their Short- and Long-Term Effects on the Chinese Economy”, Energy Economics, No. 32: 3-14.

Torul, O.; Alper, C. E. (2010), "Asymmetric Effects of Oil Price on the Manufacturing Sector in Turkey", Review of Middle East Economics and Finance, Vol. 6, No. 1: Article 4.

Uri, N. D. (1996), "Changing Crude Oil Price Effects on US Agricultural Employment", Energy Economics, Vol.18, No. 3: 185-202.

Yahia, A.; Saleh, A. (2008), "Economic Sanctions, Oil Price Fluctuations and Employment: New Empirical Evidence from Libya", American Journal of Applied Sciences, Vol. 5, No. 12: 1713-1719.

Yardımcıoğlu, F.; Beşel, F. (2013), "İşsizlik - Petrol Fiyatları ilişkisi: Yapısal Kırılmalar Altında Türkiye Örneği (1980-2012)", Turkish Studies, Vol. 8, No. 8: 2197-2211.

Yılancı, V. (2017), “Petrol Fiyatları ile Ekonomik Büyüme Arasındaki Ilişsinin İncelenmesi: Fourier Yaklaşımı", Ekonometri ve İstatistik, No. 27: 51-67.

Zivot, E.; Andrews, D. W. K. (1992), "Further Evidence on the Great Crash, the Oil-Price Shock, and the Unit-Root Hypothesis", Journal of Business \& Economic Statistics, Vol. 10, No. 3: 251-270.

"Main Economic Indicators", https://stats.oecd.org/viewhtml.aspx?datasetcode=MEl\&lang=en, (Erişim: 12.02.2021).

"Mevsim Etkisinden Arındırılmış Temel İşgücü Göstergeleri" https://data.tuik.gov.tr/Kategori/GetKategori?p=Istihdam,-Issizlik-ve-Ucret-108, (Erişim: 12.02.2021).

"Spot Prices for Crude Oil and Petroleum Products", https://www.eia.gov/dnav/pet/pet_pri_spt_s1_d.htm, (Erişim: 11.02.2021). 
EK 1. CUSUM ve CUSUMQ Grafikleri
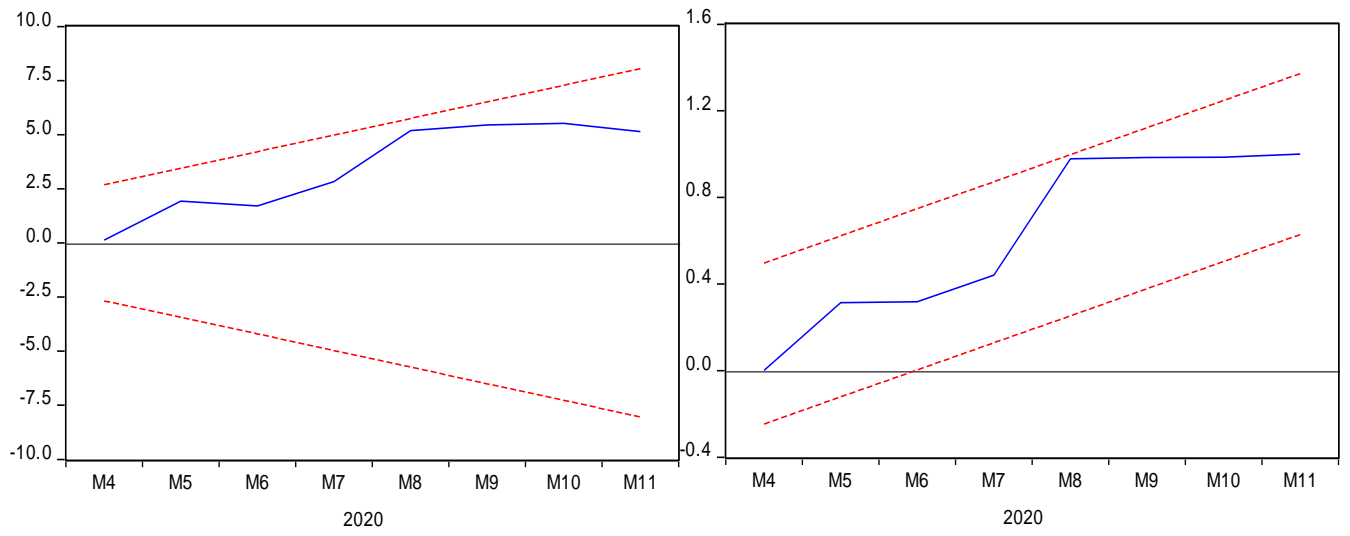

$$
\text { __ CUSUM _--- } 5 \% \text { Significance }
$$$$
\text { _ CUSUM of Squares _-_-- 5\% Significance }
$$

EK 2. Tanımlayıcı İstatistikleri

\begin{tabular}{lccc}
\hline & LNOIL & LNEMP & LNPOP \\
\hline Ortalama & 4.286 & 15.410 & 17.826 \\
\hline Medyan & 4.296 & 15.430 & 17.830 \\
\hline Maksimum & 4.965 & 15.566 & 17.959 \\
\hline Minimum & 2.833 & 15.207 & 17.685 \\
\hline St. Sapma & 0.380 & 0.102 & 0.080 \\
\hline Çarpıklık & -0.476 & -0.320 & -0.090 \\
\hline Basıklık & 3.107 & 1.797 & 1.756 \\
\hline Gözlem sayısı & 191 & 191 & 191 \\
\hline
\end{tabular}




\section{Extended Summary}

\section{The Asymmetric Effects of Oil Prices on Employment: Evidence from NARDL Approach in the Case of Turkey}

Since oil is one of the most critical inputs of any production activity, it maintains its importance as a major cost of production. In this context, the relationship between oil prices and macroeconomic performance stands out as a research area that keeps up-to-date. In earlier studies, the potential negative relationship between oil prices and economic performance has been questioned, which mainly drew attention to the effect of oil price shocks on production costs and supply in samples of developed countries, especially the USA. In the following studies, findings have been supported in different developed country samples and using different methods, attention has been drawn to the different channels that mediated the effect of oil prices on economic activity, the continuity of the relationship over time has been discussed, and the potential asymmetric effects of oil prices on economic activity have been questioned. As a developing and net oil importer country, Turkey differs from the developed countries and the oilproducing/exporting countries due to the lack of pricing power in the oil market. In this context, while oil prices are exogenous, Turkey's dependence on oil to sustain its economic activity causes the economic effects of the changes in oil prices to be more pronounced.

In the studies discussing the effects of changes in oil prices on the economy, various transmission channels that mediate the emergence of these effects have been highlighted. The prominent of these channels are the supply shock channel, the income transfer channel, the real balances channel, the monetary policy channel, the labor redistribution channel and the uncertainty channel. Besides, theoretically, monetary policy, labor redistribution, and uncertainty channels have advantages in explaining the asymmetric effects of oil price changes on economic aggregates.

In this paper, handled within the framework of these observations, the asymmetric effects of oil price changes on employment have been analyzed for the industrial sector where the intensity of oil use is relatively high and therefore, the effects of oil prices are expected to be felt more intensely in Turkey. In this context, this paper aims to answer if there is a long-run relationship between oil prices and employment. If so, is this relationship asymmetric? Finally, if there is an asymmetry between variables, which channel has explanatory power in Turkey case?

To analyze the long-run and short-run asymmetric effects, this paper has utilized the NARDL approach to cointegration. The dataset used in the analysis consists of real oil prices, industrial employment and non-institutional working-age population variables covering the period of 2005M1-2020M11. In the analysis that basically questions the asymmetric effects of oil prices on industrial employment, the working-age population variable, which is the main source of employment, has been included in the model symmetrically for control purposes. Additionally, the dummy variable, which was defined to take the value of 1 in March 2020 and after, has been added to the model deterministically to capture the effects of the COVID-19 pandemics on employment. As a result of the analysis performed within this framework, it has been concluded that there is a long-term relationship between the variables and that the assumption of asymmetry is valid in both the short and long-run. According to the results, decreases in oil prices, as well as increases, affect employment negatively and significantly in the long-run. The findings of dynamic multipliers reveal that the effects of the short-run oil price shocks, which cause instabilities on employment, maintain its destabilizing effect even in the long-run relatively balanced path.

As mentioned above, three of the transmission channels have the ability to explain asymmetry. However, in Turkey case, the monetary policy channel seems less suspicious due to the existence of an independent central bank targeting price stability in the period subject to the analysis. On the other hand, in Turkey, where the unemployment rates are constantly above the natural rate, causing a large number of reserve workforce, the labor redistribution channel is far from a sufficient argument to explain the asymmetric effects of oil prices. Therefore, in this paper, the uncertainty channel of oil prices, which explains the relationship between oil prices and real economic activity, has been highlighted in explaining the asymmetric effect in Turkey case. According to the author, in this context, the uncertainty that emerges in the form of the unpredictability of oil prices would delay the investments of investors who cannot make inferences about cost conditions, thus reducing production and employment. Besides, the uncertainty of oil prices may cause the existing firms to become uncertain about pricing and thus have negative effects on production and hence employment. Finally, in an environment of insecurity created by the price uncertainty, monetary authorities would prefer higher interest rates for the sustainability of foreign capital flow, and rising interest rates would reduce investments and production. The author emphasized that the findings of the study provide motivation to concentrate econometrically on the effects of oil price uncertainty on employment by using specific uncertainty series in future studies. 